\title{
JENIS DAN DOSIS AKTIVATOR PADA PEMBUATAN KOMPOS BERBAHAN BAKU MAKROALGA
}

\author{
Endang Susianingsih dan Nurbaya \\ Balai Riset Perikanan Budidaya Air Payau \\ Jl. Makmur Dg. Sitakka No. 129, Maros 90512, Sulawesi Selatan \\ E-mail: litkanta@yahoo.com/e_sisy@yahoo.com
}

\section{ABSTRAK}

Kompos (pupuk organik) merupakan salah satu bahan yang dapat digunakan untuk meningkatkan kesuburan tanah karena dapat meningkatkan retensi/ketersediaan hara di dalam tanah sebagai upaya untuk memperbaiki sifat kimia, fisika, dan biologi tanah. Salah satu material organik yang dapat dijadikan sebagai bahan baku pembuatan kompos adalah makroalga dari jenis rumput laut terutama dari jenis yang kurang memiliki nilai ekonomis (fluktuasi harga) dan dari jenis yang pertumbuhannya cepat karena dapat menjadi limbah dalam perairan. Teknologi pengomposan sangat beragam, di antaranya dengan penggunaan aktivator yang bertujuan untuk mempercepat proses pengomposan. Beberapa aktivator komersil telah banyak beredar di pasaran sesuai dengan peruntukan dan keunggulannya masing-masing. Akan tetapi aktivator yang diperoleh dari bahan baku yang akan dijadikan kompos atau pupuk organik belum banyak dilakukan begitu pula mengenai dosis penggunaannya. Oleh karena itu, penelitian ini bertujuan untuk mengetahui jenis dan dosis aktivator komersil dan aktivator hasil isolasi yang sesuai dan dapat digunakan untuk pembuatan kompos berbahan baku makroalga. Sebanyak 3 jenis makroalga yang digunakan sebagai bahan baku yaitu: Sargassum sp., E. spinosum, dan Gracilaria sp., menggunakan 2 (dua) jenis aktivator yaitu aktivator hasil isolasi dari bahan baku dan EM 4 sebagai aktivator pembanding dengan 3 tingkatan dosis aktivator $10^{4}, 10^{6}$, dan $10^{8} \mathrm{CFU} / \mathrm{mL}$. Peubah yang diamati meliputi perubahan kompos yang terjadi secara morfologi pada akhir penelitian, suhu, kadar C-organik, N-total, P, dan K. Hasil penelitian menunjukkan bahwa penggunaan Sargassum dengan aktivator hasil isolasi pada dosis $10^{8} \mathrm{CFU} / \mathrm{mL}$ menghasilkan kompos dengan mutu yang lebih baik.

KATA KUNCI: jenis, dosis, aktivator, kompos, makroalga

\section{PENDAHULUAN}

Kompos merupakan hasil penguraian parsial (tidak lengkap) dari campuran bahan-bahan organik yang mengalami proses dekomposisi atau pelapukan yang dapat dipercepat secara artifisial oleh populasi berbagai macam mikroba dalam kondisi lingkungan yang hangat, lembab, aerobik, dan anaerobik. Kompos yang digunakan sebagai pupuk disebut pula sebagai pupuk organik karena penyusunnya terdiri atas bahan-bahan organik (Indriani, 2003). Kompos sebagai hasil dari pengomposan dan merupakan salah satu pupuk organik memiliki fungsi penting terutama dalam bidang pertanian antara lain: mengandung unsur hara makro dan mikro, dapat memperbaiki struktur tanah, meningkatkan daya serap tanah terhadap air dan zat hara, memperbesar daya ikat tanah berpasir, memperbaiki drainase dan tata udara di dalam tanah, serta membantu proses pelapukan dalam tanah (Cahaya \& Nugroho, 2008).

Pada dasarnya semua bahan-bahan organik padat dapat dikomposkan. Misalnya: limbah organik rumah tangga, sampah-sampah organik pasar/kota, kertas, kotoran/limbah peternakan, limbah pertanian, limbahlimbah agroindustri, limbah-limbah perairan, limbah pabrik kertas, dan lain-lain. Salah satu bahan yang dapat dijadikan kompos dari limbah perairan adalah makroalga yang memiliki pertumbuhan yang sangat cepat seperti Sargassum atau dari tanaman air lain seperti azola, ganggang biru, enceng gondok, dan gulma air (Isroi, 2008).

Secara alami bahan-bahan organik akan mengalami penguraian di alam dengan bantuan mikroba maupun biota tanah lainnya (Anonim, 2005). Namun proses pengomposan yang terjadi secara alami berlangsung lama dan lambat. Untuk mempercepat proses pengomposan ini telah banyak dikembangkan teknologi-teknologi pengomposan salah satu di antaranya dengan penggunaan aktivator (dekomposer) yang merupakan konsorsium mikroba yang bertujuan untuk mempercepat proses dekomposisi. Aktivator (dekomposer) merupakan cairan yang berisikan mikrobia yang berfungsi mempercepat 
proses perombakan dan penguraian bahan organik pada proses pembuatan kompos aktif (Mandey et al., 2005). Salah satu aktivator yang banyak beredar di pasaran adalah EM 4 (effective microorganism) yang merupakan kultur campuran dari berbagai jenis mikroorganisme yang bermanfaat (terdiri atas bakteri fermentasi, jamur fermentasi, bakteri fotosintetik, bakteri pelatur fosfat, dan ragi) yang dapat dimanfaatkan sebagai inokulum untuk meningkatkan keragaman mikrobia tanah. Selain aktivator yang sudah banyak beredar di pasaran, pada penelitian ini juga coba dihasilkan aktivator yang diisolasi dari bahan baku yang akan dijadikan kompos, sehingga hasil yang diperoleh diharapkan dapat dijadikan pembanding dari aktivator komersil.

\section{TUJUAN DAN SASARAN}

\section{Tujuan}

Penelitian ini bertujuan untuk mengetahui jenis dan dosis aktivator komersil dan aktivator hasil isolasi yang sesuai dan dapat digunakan untuk pembuatan kompos berbahan baku makroalga.

\section{Sasaran}

Didapatkannya jenis dan dosis aktivator yang sesuai untuk pembuatan kompos berbahan baku makroalga.

\section{BAHAN DAN METODE}

\section{Prosedur Penelitian}

Penelitian ini dilakukan dalam 2 (dua) tahap, yaitu tahap persiapan bakteri dan tahap aplikasinya sebagai aktivator pada pembuatan kompos.

\section{Persiapan Bakteri}

Aktivator yang digunakan terdiri atas 2 (dua) jenis yaitu aktivator komersil dan kandidat aktivator. Aktivator komersil menggunakan EM 4 atau effective microorganism yang mengandung bakteri fermentasi dari genus Lactobacillus, jamur fermentasi, Actinomycetes bakteri fotosintetik, bakteri pelarut fosfat, dan ragi, sedangkan kandidat aktivator yang digunakan merupakan hasil isolasi dari makroalga sebagai bahan baku, yaitu dari jenis Sargassum, Euchema spinosum, dan Gracilaria sp. Dari beberapa isolat bakteri sebagai kandidat aktivator berdasarkan hasil uji aktivitas terhadap proteinase, amylase, selulose, dan kitinase, serta pewarnaan gram diperoleh 3 (tiga) jenis bakteri sebagai kandidat aktivator yaitu dengan kode isolat no. 18, 31, dan 58. Pemilihan ketiga jenis bakteri ini berdasarkan nilai + (positif) dari masing-masing uji yang dilakukan. Penggunaan ke-3 jenis bakteri ini dilakukan secara bersama-sama.

\section{Pembuatan Kompos}

Proses pembuatan kompos dilakukan dengan cara: bahan baku yang sudah ada (Sargassum, E. spinosum, dan Gracilaria sp., terlebih dahulu dipotong-potong sehingga ukurannya menjadi lebih kecil dari ukuran semula. Setelah semua bahan selesai dipotong, kemudian dikeringanginkan selama kurang lebih 1 (satu) hari. Hal ini dimaksudkan agar bahan yang ada tidak menjadi terlalu kering karena proses pengomposan dapat terjadi jika kelembaban dari bahan baku cukup tinggi ( $\pm 60 \%$ ). Bahan baku yang sudah dikeringanginkan lalu ditimbang masing-masing sebanyak $2 \mathrm{~kg}$ dan diletakkan ke dalam waskom. Ke dalam masing-masing wadah yang telah berisi bahan baku kemudian dimasukkan masing-masing aktivator. Penelitian ini menggunakan dua jenis aktivator yaitu aktivator komersil (EM 4 = effective microorganism) dan kandidat aktivator dari bakteri hasil isolasi. Penggunaan aktivator komersil digunakan sebagai pembanding dari kandidat aktivator yang dihasilkan. Masing-masing aktivator diberikan sebanyak $1 \mathrm{~mL} / \mathrm{kg}$ bahan, kemudian diberi $1 \frac{2}{2}$ sendok teh gula pasir. Dosis aktivator yang diberikan dibagi dalam 3 (tiga) tingkat yaitu $10^{4} \mathrm{CFU} / \mathrm{mL}, 10^{6} \mathrm{CFU} / \mathrm{mL}$, dan $10^{8} \mathrm{CFU} / \mathrm{mL}$. Kemudian diaduk-aduk secara merata sehingga terjadi pencampuran secara sempurna. Masing-masing perlakuan tersebut kemudian dimasukkan ke dalam wadah berupa karung plastik yang masih memiliki pori-pori sehingga pertukaran udara masih memungkinkan untuk terjadi karena proses pengomposan dilakukan dalam kondisi yang aerob. Dasar tempat diletakkannya wadah pengomposan selama proses fermentasi diberi sekam padi setinggi \pm 3-5 cm. Pengukuran suhu awal kemudian dilakukan untuk mengetahui fluktuasi suhu yang terjadi selama proses fermentasi (karena perubahan suhu dapat dijadikan sebagai salah satu indikasi berhasilnya proses pengomposan yang dilakukan). Fermentasi dilakukan selama 18 hari (2-3 minggu) dan setiap 3 hari sekali dilakukan pengadukan, pembalikan, serta pengukuran suhu.

Penelitian ini dilakukan dengan menggunakan 3 (tiga) jenis makroalga sebagai bahan baku pembuatan kompos, 2 (dua) jenis aktivator, 3 (tiga) tingkat dosis aktivator yang masing-masing diulang sebanyak 3 (tiga) kali sehingga terdapat 54 satuan percobaan. Peubah yang diamati dalam penelitian ini adalah perubahan suhu (yang diukur pada awal dan setiap tiga hari sekali) serta kandungan C, N, P, dan Kyang diukur pada awal dan akhir penelitian. 


\section{HASIL DAN BAHASAN}

\section{Morfologi dan Karakterisasi Bakteri Kandidat Aktivator Hasil Isolasi}

Secara morfologi bentuk ke-3 jenis bakteri kandidat aktivator tersebut dapat dilihat pada Gambar 1 .

Karakterisasi masing-masing isolat tersebut adalah: untuk isolat bakteri kode 18 mempunyai bentuk tidak beraturan, permukaannya datar agak bergelembung dan berwarna putih, untuk isolat bakteri kode 31 mempunyai bentuk yang bulat, permukaannya licin cembung, dan berwarna merah bata muda sedangkan untuk isolat bakteri dengan kode 58 mempunyai bentuk tidak beraturan, menyerupai kawah dan berwarna putih liat.
Penggunaan ke-3 isolat bakteri sebagai kandidat aktivator ini dilakukan secara bersama-sama. Hal ini dimaksudkan untuk mendapatkan hasil degradasi secara maksimal dari ketiganya karena pengujian aktivitasnya secara sendiri-sendiri terhadap bahan baku yang digunakan tidak dilakukan pada penelitian ini.

\section{Suhu}

Hasil pengukuran suhu selama penelitian dapat dilihat pada Gambar 2.

Dari Gambar 2 terlihat bahwa untuk semua perlakuan suhu rata-rata cenderung mengalami kenaikan selama proses fermentasi yaitu mulai hari ke-3 hingga hari ke15 dan pada hari ke-18 fermentasi suhu rata-rata kembali

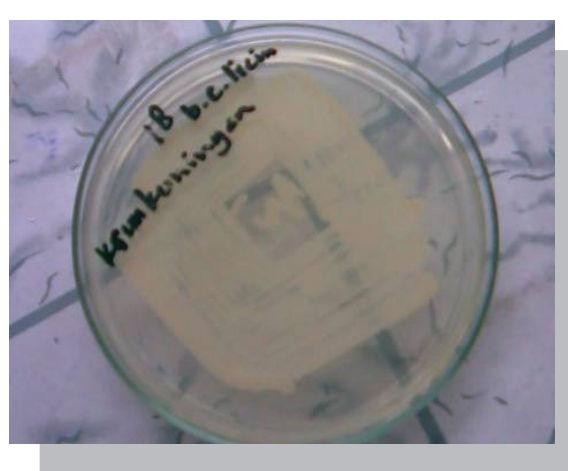

Isolat bakteri kode 18

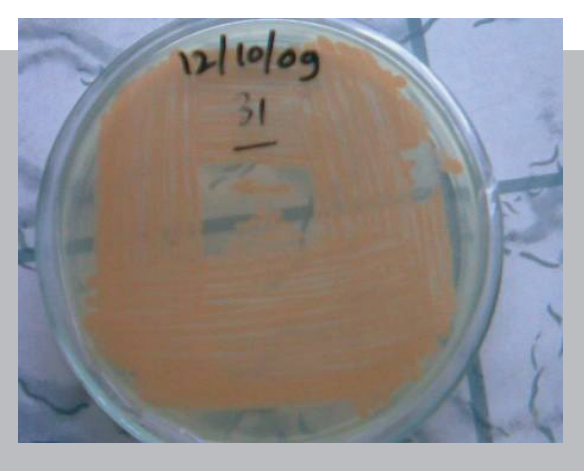

Isolat bakteri kode 31

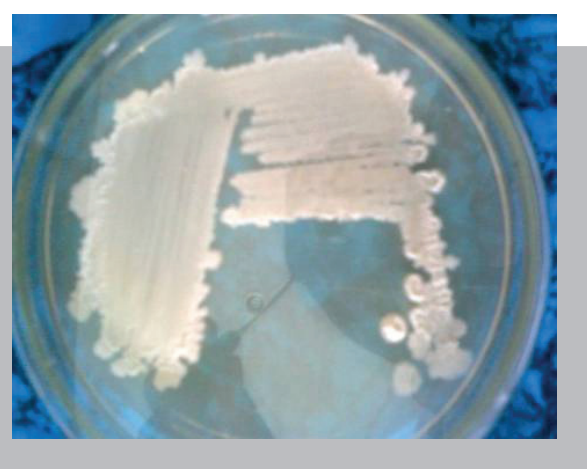

Isolat bakteri kode 58

Gambar 1. Karakterisasi isolat bakteri

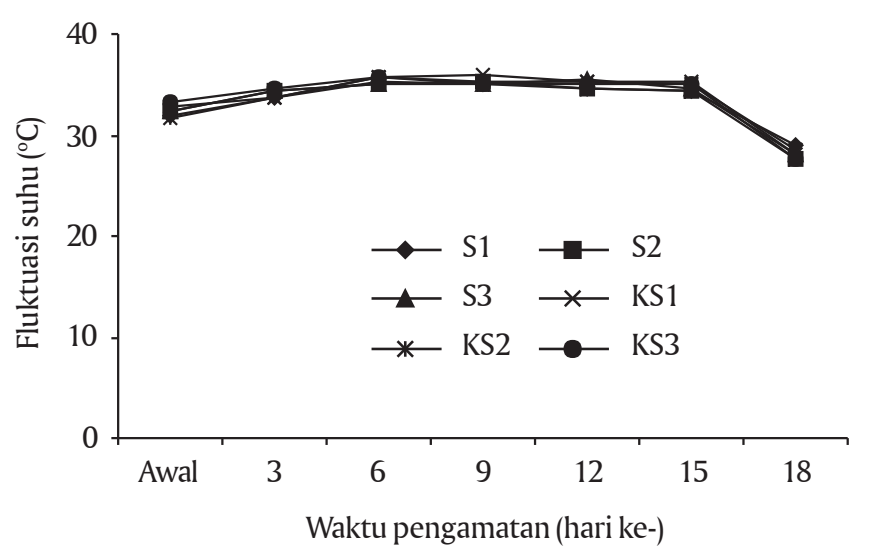

Keterangan:

$\mathrm{S} 1=$ Sargassum dengan dosis aktivator hasil isolasi $10^{4} \mathrm{CFU} / \mathrm{mL}$

$\mathrm{S} 2=$ Sargassum dengan dosis aktivator hasil isolasi $10^{6} \mathrm{CFU} / \mathrm{mL}$

$\mathrm{S} 3=$ Sargassum dengan dosis aktivator hasil isolasi $10^{8} \mathrm{CFU} / \mathrm{mL}$

$\mathrm{KS} 1$ = Sargassum dengan dosis aktivator EM $410^{4} \mathrm{CFU} / \mathrm{mL}$

$\mathrm{KS} 2$ = Sargassum dengan dosis aktivator EM $410^{6} \mathrm{CFU} / \mathrm{mL}$

$\mathrm{KS} 3=$ Sargassum dengan dosis aktivator EM $410^{8} \mathrm{CFU} / \mathrm{mL}$

Gambar 2. Fluktuasi suhu pada pembuatan kompos berbahan baku Sargassum dengan penggunaan aktivator EM 4 dan aktivator hasil isolasi dari bahan baku selama penelitian menurun, di mana suhu tertinggi pada perlakuan aktivator hasil isolasi dengan dosis $10^{4} \mathrm{CFU} / \mathrm{mL}$ diperoleh pada suhu $35,3^{\circ} \mathrm{C}$ (pada hari ke-6), untuk dosis $10^{6} \mathrm{CFU} / \mathrm{mL}$ diperoleh suhu $35,3^{\circ} \mathrm{C}$ (hari ke-9) dan untuk dosis $10^{8} \mathrm{CFU} / \mathrm{mL}$ diperoleh suhu $35,6^{\circ} \mathrm{C}$ (hari ke-12). Untuk fermentasi dengan menggunakan aktivator EM 4 maka perubahan suhu untuk dosis $10^{4} \mathrm{CFU} / \mathrm{mL}$ diperoleh suhu $35,7^{\circ} \mathrm{C}$ (hari ke-6), untuk dosis $10^{6} \mathrm{CFU} / \mathrm{mL}$ diperoleh suhu $35,7^{\circ} \mathrm{C}$ (hari ke-6) dan untuk dosis $10^{8} \mathrm{CFU} / \mathrm{mL}$ diperoleh suhu $35,7^{\circ} \mathrm{C}$ (hari ke-6). Untuk lebih jelasnya fluktuasi suhu yang terjadi selama proses fermentasi pada pembuatan kompos dengan bahan baku Sargassum dapat dilihat pada Tabel 1 .

Dari Tabel 1 terlihat bahwa suhu puncak yang diperoleh untuk perlakuan dengan penggunaan EM 4 pada dosis $10^{4}$ $\mathrm{CFU} / \mathrm{mL}$ adalah $35,3^{\circ} \mathrm{C}$ (hari ke-6), pada dosis $10^{6} \mathrm{CFU} / \mathrm{mL}$ $35,3^{\circ} \mathrm{C}$ (hari ke-9) dan pada dosis $10^{8} \mathrm{CFU} / \mathrm{mL}$ adalah $35,6^{\circ} \mathrm{C}$ (hari ke-12). Untuk suhu puncak yang diperoleh dengan penggunaan aktivator hasil isolasi pada dosis $10^{4}$ $\mathrm{CFU} / \mathrm{mL}$ adalah $35,7^{\circ} \mathrm{C}$ (hari ke-6), pada dosis $10^{6} \mathrm{CFU} / \mathrm{mL}$ $35,7^{\circ} \mathrm{C}$ (hari ke-6), dan pada dosis $10^{8} \mathrm{CFU} / \mathrm{mL}$ adalah $35,7^{\circ} \mathrm{C}$ (hari ke-6). 
Tabel 1. Hasil pengukuran suhu pada pembuatan kompos berbahan baku Sargassum dengan penggunaan aktivator EM 4 dan aktivator hasil isolasi dari bahan baku selama penelitian

\begin{tabular}{|c|c|c|c|c|c|c|c|c|c|c|c|c|c|c|c|c|c|c|c|c|}
\hline \multicolumn{21}{|c|}{ Sargassum (dosis) } \\
\hline \multicolumn{7}{|c|}{$10^{4} \mathrm{CFU} / \mathrm{mL}$} & \multicolumn{7}{|c|}{$10^{6} \mathrm{CFU} / \mathrm{mL}$} & \multicolumn{7}{|c|}{$10^{8} \mathrm{CFU} / \mathrm{mL}$} \\
\hline Awal & 3 & 6 & 9 & 12 & 15 & 18 & Awal & 3 & 6 & 9 & 12 & 15 & 18 & Awal & 3 & 6 & 9 & 12 & 15 & 18 \\
\hline 32 & 33,6 & 35,3 & 35 & 34,7 & 34,3 & 29 & 32,3 & 34,3 & 35 & 35,3 & 34,7 & 34,3 & 27,6 & 32,3 & 34,3 & 35 & 35 & 35,6 & 34,7 & 28 \\
\hline K 32,7 & 33,6 & 35,7 & 35 & 35,3 & 35,3 & 28 & 31,7 & 33,6 & 35,7 & 35 & 35,3 & 35 & 28,6 & 33,3 & 34,7 & 35,7 & 33,5 & 35 & 35 & 27,7 \\
\hline
\end{tabular}

Hasil fluktuasi suhu yang diperoleh secara deskriptif menunjukkan bahwa penggunaan aktivator EM 4 dengan aktivator hasil isolasi tidak menunjukkan adanya perbedaan terhadap perubahan suhu yang terjadi selama proses fermentasi (18 hari pengamatan).

Untuk perubahan suhu yang terjadi pada pembuatan kompos dengan bahan baku E. spinosum dapat dilihat pada Gambar 3.

Dari Gambar 3 terlihat bahwa dengan bahan baku $E$. spinosum untuk semua perlakuan suhu rata-rata cenderung mengalami fluktuasi naik dan turun selama proses fermentasi. Pada hari ke-3 untuk semua perlakuan suhu rata-rata mengalami penurunan dari suhu awal pengukuran, pada hari ke-6 suhu rata-rata kembali naik dan kecenderungan tersebut nampaknya terjadi hingga pada akhir penelitian (hari ke-18), kecuali pada perlakuan dengan dosis $10^{4} \mathrm{CFU} / \mathrm{mL}$ suhu rata-rata pada hari ke-6,

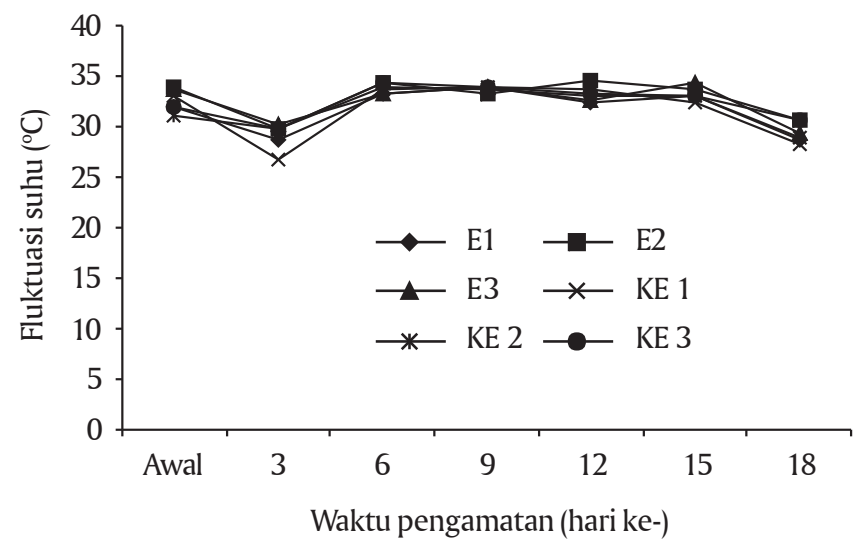

Keterangan:

$\mathrm{E} 1=$ E. spinosum dengan dosis aktivator hasil isolasi $10^{4} \mathrm{CFU} / \mathrm{mL}$

$\mathrm{E} 2=$ E. spinosum dengan dosis aktivator hasil isolasi $10^{6} \mathrm{CFU} / \mathrm{mL}$

E3 = E. spinosum dengan dosis aktivator hasil isolasi $10^{8} \mathrm{CFU} / \mathrm{mL}$

$\mathrm{KE} 1=$ E. spinosum dengan dosis aktivator EM $410^{4} \mathrm{CFU} / \mathrm{mL}$

$\mathrm{KE} 2=$ E. spinosum dengan dosis aktivator EM $410^{6} \mathrm{CFU} / \mathrm{mL}$

$\mathrm{KE} 3=$ E. spinosum dengan dosis aktivator EM $410^{8} \mathrm{CFU} / \mathrm{mL}$

Gambar 3. Fluktuasi suhu pada pembuatan kompos berbahan baku $E$. spinosum dengan penggunaan aktivator EM 4 dan aktivator hasil isolasi dari bahan baku selama penelitian mengalami kenaikan pada hari ke-9. Untuk proses fermentasi dengan penggunaan aktivator EM 4 untuk semua perlakuan, suhu rata-rata yang pada hari ke-3 mengalami penurunan dari pengukuran suhu awal, kemudian mengalami kenaikan hingga hari ke-9. Untuk lebih jelasnya fluktuasi suhu yang terjadi selama proses fermentasi pada pembuatan kompos dengan bahan baku Sargassum dapat dilihat pada Tabel 2.

Tabel 2 memperlihatkan bahwa suhu puncak yang diperoleh untuk perlakuan dengan penggunaan EM 4 pada dosis $10^{4} \mathrm{CFU} / \mathrm{mL}$ adalah $34^{\circ} \mathrm{C}$ (hari ke-9), pada dosis $10^{6}$ $\mathrm{CFU} / \mathrm{mL} 34,6^{\circ} \mathrm{C}$ (hari ke-12) dan pada dosis $10^{8} \mathrm{CFU} / \mathrm{mL}$ adalah $34,3^{\circ} \mathrm{C}$ (hari ke-15). Untuk suhu puncak yang diperoleh dengan penggunaan aktivator hasil isolasi pada dosis $10^{4} \mathrm{CFU} / \mathrm{mL}$ adalah $34^{\circ} \mathrm{C}$ (hari ke-9), pada dosis $10^{6}$ $\mathrm{CFU} / \mathrm{mL} 34^{\circ} \mathrm{C}$ (hari ke-6) dan pada dosis $10^{8} \mathrm{CFU} / \mathrm{mL}$ adalah $34,3^{\circ} \mathrm{C}$ (hari ke-6).

Untuk perubahan suhu yang terjadi pada pembuatan kompos dengan bahan baku Gracilaria dapat dilihat pada Gambar 4.

Dari Gambar 4 terlihat bahwa suhu rata-rata untuk aktivator hasil isolasi cenderung mengalami kenaikan mulai hari ke-3 pengukuran hingga hari ke-9, kemudian tetap hingga hari ke-15 dan mengalami penurunan pada hari ke-18. Untuk perlakuan dengan penggunaan aktivator EM 4 kecenderungan yang sama juga terlihat di mana suhu rata-rata mengalami kenaikan mulai hari ke-6 hingga hari ke-9, hari ke-12 dan ke-15 tetap, kemudian turun pada hari ke-18. Untuk lebih jelasnya fluktuasi tersebut dapat dilihat pada Tabel 3.

Dari Tabel 3 terlihat bahwa suhu puncak yang diperoleh untuk perlakuan dengan penggunaan EM 4 pada dosis $10^{4}$ $\mathrm{CFU} / \mathrm{mL}$ adalah $35^{\circ} \mathrm{C}$ (hari ke-9 dan ke-15), pada dosis $10^{6}$ $\mathrm{CFU} / \mathrm{mL} 34,7^{\circ} \mathrm{C}$ (hari ke-6, 9, dan 15) dan pada dosis $10^{8}$ $\mathrm{CFU} / \mathrm{mL}$ adalah $36^{\circ} \mathrm{C}$ (hari ke-9). Untuk suhu puncak yang diperoleh dengan penggunaan aktivator hasil isolasi pada dosis $10^{4} \mathrm{CFU} / \mathrm{mL}$ adalah $34,7^{\circ} \mathrm{C}$ (hari ke-12), pada dosis

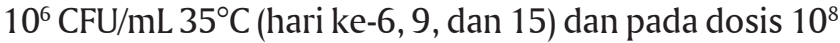
$\mathrm{CFU} / \mathrm{mL}$ adalah $34,3^{\circ} \mathrm{C}$ (hari ke-6 dan 15 ). 
Tabel 2. Hasil pengukuran suhu pada pembuatan kompos berbahan baku E. spinosum dengan penggunaan aktivator EM 4 dan aktivator hasil isolasi dari bahan baku selama penelitian

\begin{tabular}{|c|c|c|c|c|c|c|c|c|c|c|c|c|c|c|c|c|c|c|c|c|c|}
\hline \multicolumn{22}{|c|}{ E. spinosum (dosis) } \\
\hline \multicolumn{8}{|c|}{$10^{4} \mathrm{CFU} / \mathrm{mL}$} & \multicolumn{7}{|c|}{$10^{6} \mathrm{CFU} / \mathrm{mL}$} & \multicolumn{7}{|c|}{$10^{8} \mathrm{CFU} / \mathrm{mL}$} \\
\hline & Awal & 3 & 6 & 9 & 12 & 15 & 18 & Awal & 3 & 6 & 9 & 12 & 15 & 18 & Awal & 3 & 6 & 9 & 12 & 15 & 18 \\
\hline & 32,0 & 28,7 & 33,3 & 34,0 & 32,3 & 33,0 & 28,7 & 34,0 & 29,7 & 34,3 & 33,3 & 34,6 & 33,6 & 30,6 & 33,7 & 30,3 & 33,3 & 34,0 & 32,7 & 34,3 & 29,3 \\
\hline K & 33,0 & 26,7 & 33,6 & 34,0 & 33,7 & 32,3 & 28,3 & 31,0 & 29,7 & 34,0 & 33,7 & 33,0 & 33,0 & 29,0 & 32,0 & 29,7 & 34,3 & 34,0 & 33,3 & 33,0 & 30,7 \\
\hline
\end{tabular}

Tabel 3. Hasil pengukuran suhu pada pembuatan kompos berbahan baku Gracilaria dengan penggunaan aktivator EM 4 dan aktivator hasil isolasi dari bahan baku selama penelitian

\begin{tabular}{|c|c|c|c|c|c|c|c|c|c|c|c|c|c|c|c|c|c|c|c|c|}
\hline \multicolumn{21}{|c|}{ Gracilaria (dosis) } \\
\hline \multicolumn{7}{|c|}{$10^{4} \mathrm{CFU} / \mathrm{mL}$} & \multicolumn{7}{|c|}{$10^{6} \mathrm{CFU} / \mathrm{mL}$} & \multicolumn{7}{|c|}{$10^{8} \mathrm{CFU} / \mathrm{mL}$} \\
\hline Awal & 3 & 6 & 9 & 12 & 15 & 18 & Awal & 3 & 6 & 9 & 12 & 15 & 18 & Awal & 3 & 6 & 9 & 12 & 15 & 18 \\
\hline 34 & 32,3 & 34,7 & 35 & 32,3 & 35 & 29,3 & 36 & 32,3 & 34,3 & 34,7 & 32,3 & 34,7 & 30 & 35 & 32 & 35,6 & 36 & 33,3 & 35 & 28,7 \\
\hline K 35,7 & 32,7 & 34,6 & 35 & 34,7 & 34,3 & 29,3 & 33 & 33 & 35 & 35 & 35 & 34 & 28,7 & 32 & 32,3 & 34,3 & 34 & 34 & 34,3 & 30 \\
\hline
\end{tabular}

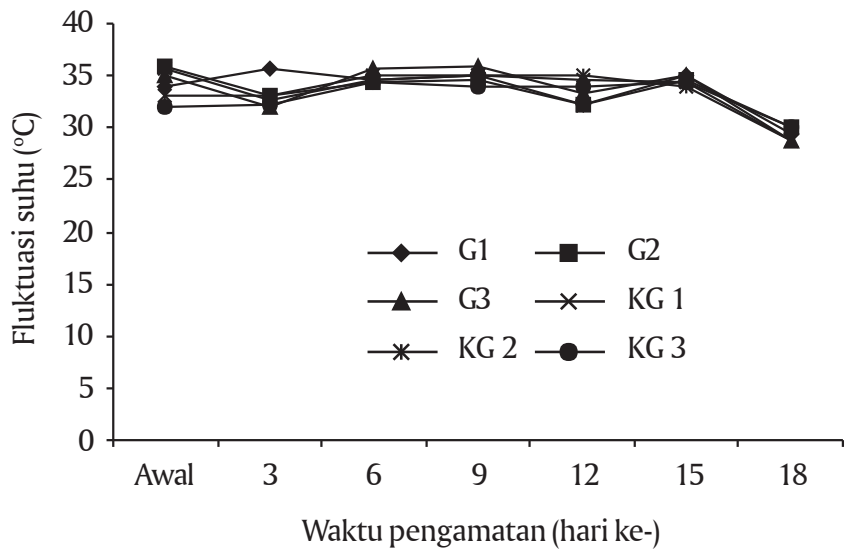

Keterangan:

$\mathrm{G} 1=$ Gracilaria dengan dosis aktivator hasil isolasi $10^{4} \mathrm{CFU} / \mathrm{mL}$

$\mathrm{G} 2$ = Gracilaria dengan dosis aktivator hasil isolasi $10^{6} \mathrm{CFU} / \mathrm{mL}$

$\mathrm{G} 3=$ Gracilaria dengan dosis aktivator hasil isolasi $10^{8} \mathrm{CFU} / \mathrm{mL}$

$\mathrm{KG} 1=$ Gracilaria dengan dosis aktivator EM $410^{4} \mathrm{CFU} / \mathrm{mL}$

$\mathrm{KG} 2=$ Gracilaria dengan dosis aktivator EM $410^{6} \mathrm{CFU} / \mathrm{mL}$

$\mathrm{KG} 3=$ Gracilaria dengan dosis aktivator EM $410^{8} \mathrm{CFU} / \mathrm{mL}$

Gambar 4. Fluktuasi suhu pada pembuatan kompos berbahan baku Gracilaria dengan penggunaan aktivator EM 4 dan aktivator hasil isolasi dari bahan baku selama penelitian

Secara umum dapat dikatakan bahwa suhu rata-rata selama fermentasi telah cukup mendukung untuk terjadinya proses pengomposan di mana menurut Isroi (2008), suhu yang berkisar antara $30^{\circ} \mathrm{C}-60^{\circ} \mathrm{C}$ menunjukkan aktivitas pengomposan yang cepat, tetapi suhu yang lebih tinggi dari $60^{\circ} \mathrm{C}$ akan membunuh sebagian mikroba dan hanya mikroba termofilik saja yang akan tetap bertahan hidup.

Dari suhu rata-rata yang didapatkan pada masingmasing perlakuan yang berkisar antara $28^{\circ} \mathrm{C}-36^{\circ} \mathrm{C}$ menunjukkan bahwa variasi suhu yang terjadi selama proses pengomposan disebabkan karena adanya perbedaan pengaruh aktivitas dari masing- masing mikroorganisme yang berperan dalam proses tersebut. Pada tahap pertama menurut Cahaya \& Nugroho (2008), awal proses pengomposan merupakan tahap penghangatan (tahap mesofilik), mikroorganisme yang hadir pada saat ini merupakan mikroorganisme yang hadir secara cepat dalam bahan kompos dan menyebabkan peningkatan suhu dan mempunyai kemampuan hidup pada kisaran suhu yang cukup besar yaitu $10^{\circ} \mathrm{C}-45^{\circ} \mathrm{C}$ bertugas memperkecil ukuran partikel bahan organik sehingga luas permukaan bahan bertambah dan dapat mempercepat proses pengomposan. Tahap kedua yang mestinya terjadi adalah tahap termofilik di mana mikroorganisme termofilik yang hadir pada bahan kompos mampu hidup pada suhu $45^{\circ} \mathrm{C}$ $60^{\circ} \mathrm{C}$ dan bertugas mengonsumsi karbohidrat dan protein sehingga bahan kompos dapat terdegradsi dengan cepat. Mikroorganisme ini berupa actinomycetes dan jamur termofilik. Sebagian dari actinomycetes ini mampu merombak selulosa dan hemiselulosa. Selanjutnya dikatakan oleh Isroi (2008), aktivitas dekomposisi oleh mikroba di dalam kompos dengan menggunakan oksigen akan menguraikan bahan organik menjadi $\mathrm{CO}_{2}$, uap air, dan panas. Setelah sebagian besar bahan telah terurai maka 
suhu berangsur-angsur akan mengalami penurunan pada tahap yang disebut tahap pendinginan dan pematangan (Cahaya \& Nugroho, 2008). Pada tahap ini jumlah mikroorganisme termofilik berkurang karena bahan makanan bagi mikroorganisme ini juga berkurang, hal ini mengakibatkan organisme mesofilik mulai beraktivitas kembali dan akan merombak selulose dan hemiselulose yang tersisa dari proses sebelumnya menjadi gula yang lebih sederhana dan panas yang dilepaskan relatif lebih kecil.

\section{Kadar C, N, P, dan K}

Untuk mengetahui karakteristik kompos matang dalam hal ini perbandingan $\mathrm{C}$ dan $\mathrm{N}(\mathrm{C} / \mathrm{N}$ rasio) untuk masing-masing perlakuan maka pada akhir penelitian (18 hari pengamatan) dilakukan pengujian terhadap konsentrasi C-organik, N-total, P, dan K, serta kadar abu. Hasil analisis tersebut dapat dilihat pada Tabel 4 .

Tabel 4. Hasil analisis kadar C-organik, N-total, P, K, dan kadar abu masing-masing perlakuan

\begin{tabular}{lccccc}
\hline \multirow{2}{*}{$\begin{array}{c}\text { Kode } \\
\text { sampel }\end{array}$} & \multicolumn{5}{c}{ Hasil (\%) } \\
\cline { 2 - 6 } & C-organik & N-total & $\mathbf{P}$ & K & Kadar abu \\
\hline S1 & 13,82 & 0,37 & 0,09 & 5,81 & 18,89 \\
S2 & 12,74 & 0,59 & 0,09 & 4,55 & 17,00 \\
S3 & 11,83 & 1,10 & 0,09 & 5,59 & 8,05 \\
KS1 & 13,06 & 0,53 & 0,09 & 5,38 & 3,40 \\
KS2 & 12,63 & 0,48 & 0,09 & 4,25 & 12,45 \\
KS3 & 11,67 & 0,26 & 0,08 & 4,67 & 5,05 \\
E1 & 16,34 & 0,64 & 0,13 & 6,02 & 15,10 \\
E2 & 18,02 & 0,50 & 0,10 & 5,69 & 17,45 \\
E3 & 11,03 & 0,58 & 0,09 & 6,33 & 17,00 \\
KE1 & 17,19 & 0,48 & 0,09 & 6,85 & 17,55 \\
KE2 & 20,10 & 0,50 & 0,08 & 6,83 & 15,05 \\
KE3 & 16,61 & 0,33 & 0,10 & 7,66 & 15,15 \\
G1 & 14,14 & 0,46 & 0,07 & 8,51 & 5,80 \\
G2 & 12,74 & 0,58 & 0,07 & 8,90 & 6,50 \\
G3 & 14,00 & 0,58 & 0,07 & 7,68 & 7,50 \\
KG1 & 14,60 & 0,64 & 0,07 & 8,09 & 7,68 \\
KG2 & 14,76 & 1,13 & 0,07 & 9,53 & 7,65 \\
KG3 & 14,76 & 0,90 & 0,07 & 9,34 & 12,70 \\
\hline
\end{tabular}

Sumber: Hasil analisis laboratorium Balai Pengembangan Teknologi Pertanian Maros, Sulawesi Selatan (2009)

Tingkat kematangan kompos didasarkan pada Standar Nasional Indonesia (SNI-19-7030-2004) seperti pada Tabel 5.

Berdasarkan Tabel 5 dapat diketahui bahwa kandungan C-organik pada semua perlakuan masih memenuhi rentang
Tabel 5. Karakteristik kompos matang menurut SNI-197030-2004

\begin{tabular}{ccccccc}
\hline Batas & $\begin{array}{c}\text { C-organik } \\
(\mathbf{\%})\end{array}$ & $\begin{array}{c}\text { N-total } \\
(\mathbf{\%})\end{array}$ & Rasio C/N & $\begin{array}{c}\text { Kadar abu } \\
(\mathbf{\%})\end{array}$ & $\begin{array}{c}\text { Suhu } \\
\left({ }^{\circ} \mathbf{C}\right)\end{array}$ & pH \\
\hline Minimal & 9,8 & 0,4 & 10 & - & - & 6,8 \\
Maksimal & 32 & - & 20 & 50 & \pm 30 & 7,49 \\
\hline
\end{tabular}

Sumber: Cahaya \& Nugroho (2008)

yang disyaratkan oleh SNI-19-7030-2004 yaitu minimal 9,8 dan maksimal 32. Hasil ini menunjukkan bahwa proses dekomposisi telah berlangsung dengan baik. Hal ini kemungkinan disebabkan karena tumpukan bahan baku untuk pembuatan kompos yang digunakan tidak terlalu banyak/tebal sehingga panas yang ditimbulkan dalam proses ini secara maksimal dapat mendegradasi bahan baku sehingga dapat terdekomposisi dengan baik.

Kandungan $\mathrm{N}$ total kompos sebagian besar telah memenuhi yang dipersyaratkan oleh SNI-19-7030-2004 yaitu minimal 0,4\%, kecuali pada perlakuan S1 (Sargassum dengan aktivator hasil isolasi pada dosis $10^{4} \mathrm{CFU} /$ $\mathrm{mL}$ ), KS3 (Sargassum dengan aktivator EM 4 pada dosis $10^{8} \mathrm{CFU} / \mathrm{mL}$ ) dan $\mathrm{KE} 3$ (E. spinosum dengan aktivator EM 4 pada dosis $10^{8} \mathrm{CFU} / \mathrm{mL}$ ).

Untuk rasio C/N (C, N Rasio) dari kompos yang dihasilkan variasinya masih sangat besar. Hanya ada 4 perlakuan yang rasio $\mathrm{C}$ dan $\mathrm{N}$-nya memenuhi rentang yang disyaratkan oleh SNI-19-7030-2004 yaitu pada perlakuan S3 (Sargassum dengan aktivator hasil isolasi pada dosis $10^{8} \mathrm{CFU} / \mathrm{mL}$ ), E3 (E. spinosum dengan aktivator hasil isolasi pada dosis $10^{8} \mathrm{CFU} / \mathrm{mL}$ ), KG2 (Gracilaria dengan aktivator EM 4 pada dosis $10^{6} \mathrm{CFU} / \mathrm{mL}$ ) dan KG3 (Gracilaria dengan aktivator EM 4 pada dosis $10^{8} \mathrm{CFU} / \mathrm{mL}$ ).

\section{Morfologi Masing-masing Bahan pada Akhir Penelitian}

Perubahan secara morfologi untuk masing-masing bahan pada akhir penelitian dapat dilihat pada Gambar 5 .

Dari Gambar 5 terlihat bahwa secara morfologi kompos yang terbuat dari bahan baku Sargassum sp. memiliki karakteristik yang memenuhi persyaratan sebagai kompos yang baik (Isroi, 2008), yaitu antara lain memiliki warna coklat tua hingga hitam mirip dengan warna tanah dan memiliki tekstur yang sangat rapuh jika dibandingkan dengan dua bahan baku lainnya, Gracilaria sp. dan E. spinosum yang memiliki tekstur yang masih agak liat jika dipegang. Terhadap bau yang dihasilkan, untuk Gracilaria sp. dan Sargassum sp. tidak memiliki bau jika dibandingkan dengan E. spinosum, meskipun bau yang dihasilkan sangat khas sebagai bau yang biasa terhirup 


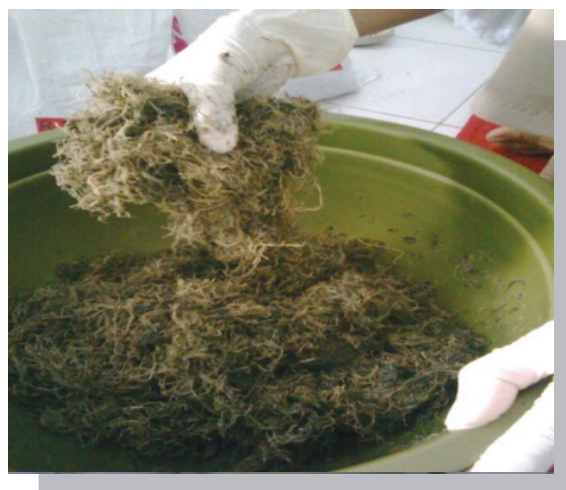

Gracilaria sp.

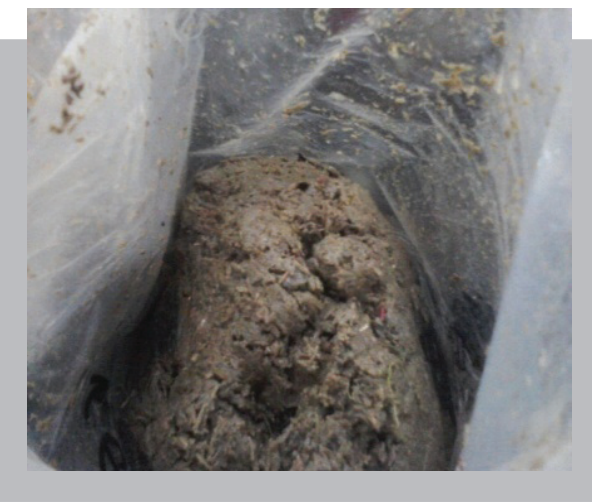

Euchema spinosum

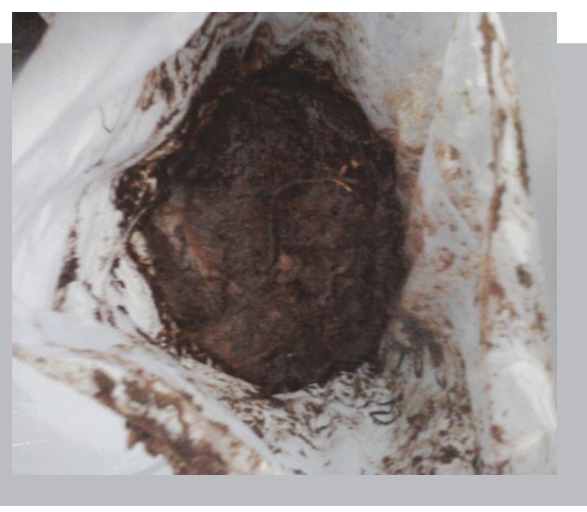

Sargassum sp.

Gambar 5. Morfologi kompos pada masing-masing bahan

dari rumput laut pada umumnya. Demikian juga suhu yang ditimbulkannya hampir sama dengan suhu lingkungan yaitu $27,7^{\circ} \mathrm{C}-35,7^{\circ} \mathrm{C}$.

\section{KESIMPULAN DAN SARAN}

Sargassum sp., E. spinosum, dan Gracilaria sp. mempunyai kemampuan untuk dijadikan sebagai alternatif bahan baku pada pembuatan kompos organik, tetapi Sargassum sp. yang didekomposisi dengan menggunakan aktivator hasil isolasi pada dosis $10^{8} \mathrm{CFU} / \mathrm{mL}$ memberikan hasil yang lebih baik dengan memiliki beberapa ciri sebagai kompos yang baik (morfologi, kandungan Corganik, N-total, rasio $\mathrm{C}$ dan $\mathrm{N}$, serta fluktuasi suhu) dibandingkan dengan E. spinosum dan Gracilaria sp.

Pengujian terhadap aktivitas masing-masing bakteri kandidat aktivator yang disolasi dari bahan baku masih perlu untuk dilakukan misalnya kemampuan untuk mendekomposisikan masing-masing bahan dan kemampuan tumbuh dari masing-masing bakteri sehingga aplikasinya dapat dilakukan secara maksimal.

\section{UCAPAN TERIMA KASIH}

Dengan terselesaikannya penelitian dan laporan hasil penelitian dengan judul Jenis dan Dosis Aktivator Pada Pembuatan Kompos Berbahan Baku Makroalga ini, terucap terima kasih kepada semua pihak yang telah turut mendukung dan memfasilitasi hingga penelitian ini dapat terlaksana utamanya kepada Dinas Pendidikan Nasional atas hibah penelitiannya dalam rangka Hibah Penelitian Bagi Peneliti dan Perekayasa, Kerja sama DKP dan Diknas Tahun 2009, serta teman-teman peneliti dan teknisi yang membantu hingga pelaksanaan penelitian ini dapat terselesaikan dengan baik. Semoga hasil yang diperoleh dapat memberikan manfaat baik kepada masyarakat pengguna maupun kepada diri pribadi kami. Amin.

\section{DAFTAR ACUAN}

Anonim. 2005. Peluang Usaha melalui Pembuatan Pupuk Kompos. Departemen Pendidikan Nasional Direktorat Jenderal Manajemen Pendidikan Dasar dan Menengah Kegiatan Peningkatan Pendidikan Kependudukan dan Lingkungan Hidup.

Cahaya, A. \& Nugroho, D.A. 2008. Pembuatan Kompos Dengan Menggunakan Limbah Padat organik. Jurusan Teknik Kimia. Fakultas Teknik. Universitas Diponegoro.

Indriani, H.Y. 2003. Membuat Kompos Secara Kilat. Penebar Swadaya. Jakarta.

Isroi. 2008. Kompos. Makalah. Balai Penelitian Bioteknologi Perkebunan. Bogor.

Mandey, L.C., Tarore, D., Santoso, R.S., \& Kandou, A. STP. Proposal. Produksi Kompos Aktif Organik dengan Menggunakan Teknologi Dekomposer dan Penerapannya Kepada Petani di Kabupaten Minahasa Utara. 